\title{
Integration of Virtual Prototyping and Building Information Modeling to Optimize the Construction Site Planning and Management
}

\author{
Abbas Mahde Abd'and Ghasaq thair Youssef ${ }^{2}$ \\ 'Department of Architectural Engineering, College of Engineering, University of Diyala, \\ Baqubah, Iraq; abbas.mahde@gmail.com \\ ${ }^{2}$ Department of Civil Engineering, College of Engineering, University of Diyala, \\ Baqubah, Iraq; ghasaq/ghasaq@gmail.com
}

\begin{abstract}
Objectives: To study the possibility of using Building Information Modeling (BIM) to improve the efficiency of site planning and management spaces within the buildings. Method: In order to achieve this study, the literature and previous research in the field has been consulted, as well as the collection of data by interviewing a group of engineers through collection of documents and maps of the project and taking realistic picture of the buildings. Findings: By analyzing case study and finding real area data by using BIM technology and comparing it with the international standards for space management on campus, there was a significant difference. And it was found that there is no international standard used in the design of these spaces and it is not suitable for student and staff and teaching staff. The researcher recommends the use of BIM technology in the early stage of the project to reduce the design error in space management and the efficiency of this technology and it's easy to obtaining information and data. Although there are obstacles to the use of BIM practices due to the reasons for the scarcity of qualified personal in this field, in the near future there will be the usage of large scale BIM system in the construction industry. Applications: BIM technology is one of the most important technologies in the construction industry and it increases the performance during project life cycle. As a result of the development of the construction industry, such technology has to be used, increasing design efficiency and improving construction work while providing more time and cost
\end{abstract}

Keywords: Building Information Modeling (BIM), Site Planning, Space Management

\section{Introduction}

Numerous studies as of late are attempting to execute the utilization of Building Information Modeling (BIM) with a specific end goal to pick up benefits in various view points of the development procedure including the administration of the development site and the utilization of models nearby. From a site configuration perspective, two fundamental viewpoints are underlined by global looks into: 4D planning, Safety or both together. 4D booking research began quite a long while back with $3 \mathrm{D}$ CAD frameworks actualized with time so as to envision the works advance. With the improvement of BIM the exploration on $4 \mathrm{D}$ planning clearly preceded onward this framework since the opportunity to embed "schedule", robotizing 1 . BIM is so different from the traditional CAD method in building design $²$. Through the use of BIM

${ }^{*}$ Author for correspondence 
approach by project participation, it is easy to exchange the information of project.

The BIM model can save the energy performance data such as power consumption, temperature, $\mathrm{CO}_{2}$ emissions, occupancy and humidity, Site planning, green technology application, and many others. The important benefit of BIM model were seen through the lower cost of construction project by making building planning, design, construction, and Maintenance more efficient and deliver better value of project ${ }^{3}$.

\section{BIM Programming}

There are arrangements of organizations that are considered as an engineer for BIM programming and these products are shifted to play out different purposes. $\mathrm{In}^{4}$ calls attention to that the major BIM Programming delivered via Autodesk, Graph iSOFT, and Bentley. BIM programming can be arranged into numerous gatherings, for example:

1. Software for compositional outline.

2. Software for auxiliary outline.

3. Software identified with supportability.

4. Software for mechanical, electrical, plumping (MEP) outline.

5. Software for estimations, reproduction, investigation and discovery of contentions.

6. Software to oversee offices.

\section{BIM Measurements}

There are a few ideas, terms and applications created over the BIM, including what is known as the BIM measurements $(3 \mathrm{D}, 4 \mathrm{D}, 5 \mathrm{D}, 6 \mathrm{D}$, and $7 \mathrm{D})$ as the BIM does not manage a $2 \mathrm{D}$ or $3 \mathrm{D}$ framework just, but instead surpassesit for different measurements. Each measurement includes certain reasons inside the development venture. Figure 1 demonstrates the measurements of the BIM and its substance.

- 3D measurement: This measurement is for perception where it enables to partners to see the working in a virtual domain before it is really manufactured and furthermore enables them to see refreshes for this Representation along the life of building ${ }^{\underline{5}-\underline{7}}$.

- 4D measurement: This measurement is worried about adding the booking to the past measurement (3D).
Through this measurement, the partners have the capacity to picture and concentrate the advance of the working exercises amid the allocated course of events ${ }^{\text {. }}$.

- 5D measurement: This measurement is worried about adding the cost to the past measurement (4D). Through this measurement, partners can assess both time and cost for everything in the venture ${ }^{8-10}$.

- 6D measurement: This measurement is worried about adding the supportability to the past measurement (5D). Through this measurement, partners can acquire exact and finish vitality estimations ${ }^{7}$.

- 7D measurement: This measurement is worried about adding the office administration to the past measurement (6D). Through this measurement, partners can oversee resources ideally through undertaking ${\text { stages }{ }^{11} \text {. }}^{1}$

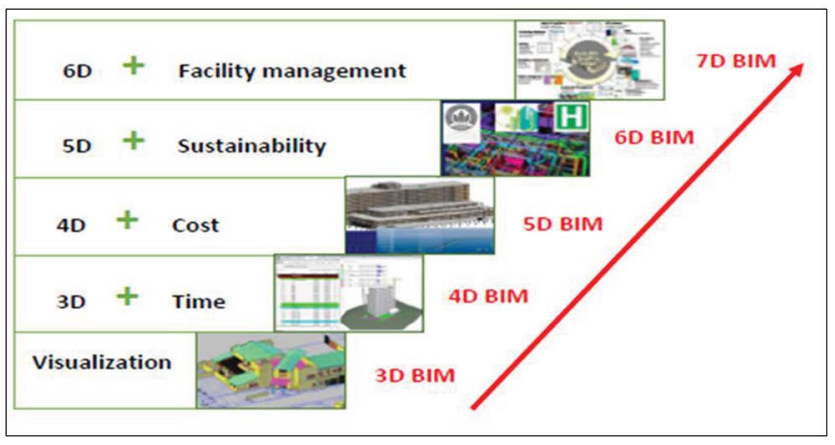

Figure 1. BIM dimensions (researcher).

\section{Research Methodology}

\subsection{Theoretical Approach}

- It will be focused on the theoretical analysis of scientific literature. It will start from the general concept of BIM as a new collaborative process, and then will continue with its analysis as an "n-D" tool.

- General concept of Building Information Modeling as a tool and process to manage information in different area of the site planning.

\subsection{Experimental Analysis}

- General site planning vs. BIM site planning comparison. This quantitative analysis for a case study 
of already existing project, based on the automatic process of extracting information from BIM models.

- Case study was modeled by Revit software according to BIM to calculate their actual area and compared with the international standard.

\section{Case study Medicine Collage}

Medicine collage is one of the important collage in diyala university campus in Iraq it consist of Six main building (deanship, library and four factual department). Local company was implemented this project. The type of contract is unit price contract and it was built in (2002). This collage has 422 students for the year of (2017-2018) for different department (Figure 2).

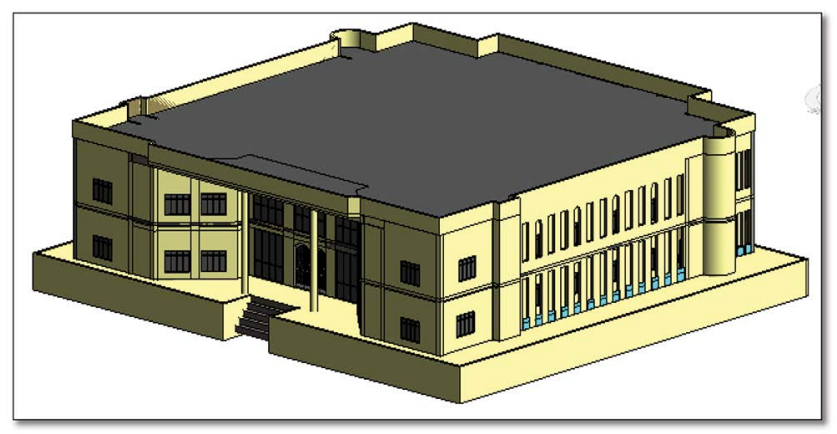

Figure 2. Deanship of medicine collage.

\section{Experimental Work}

\section{Part I: division of internal spaces of buildings}

The ground floor and first floor of internal spaces of deanship and factual department for case study should be divided into (office room, lecture hall, laboratory and service room) and the library should be divided into (library, Lecture hall, book store, office room) this process is done by using architectural tab and room panel are shown in the Figure 3.

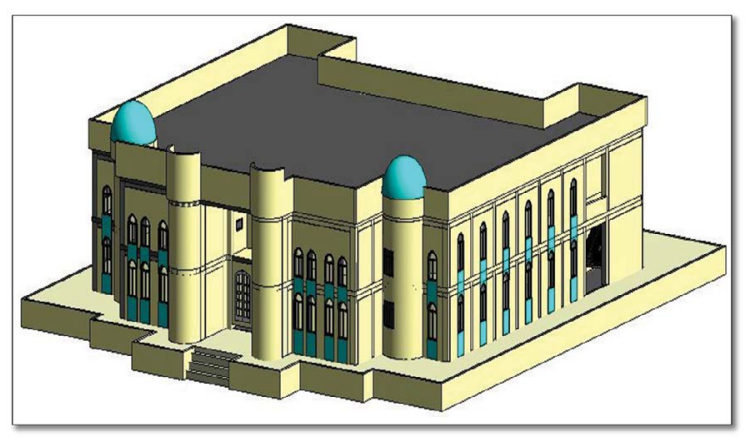

Figure 3. Library of medicine collage.

\section{Part II: rooms schedule}

Schedule is created for all building floors to determine their area. From "view" menu choose "schedule" Then chose room from "filter list" as shown in the Figure 4.

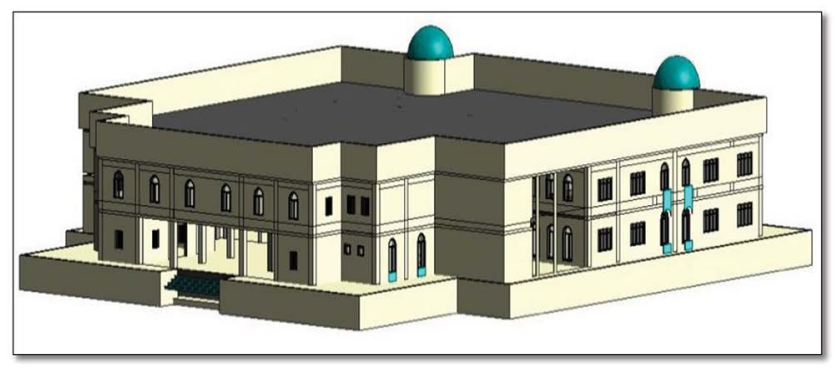

Figure 4. Factual departments of medicine collage.

Chose the flowing parameter (number, name, area, level) (Figure 5).

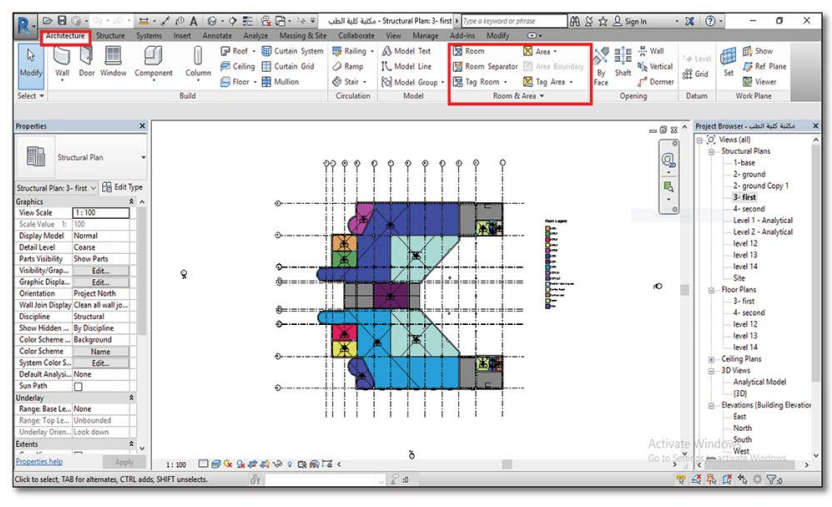

Figure 5. The division of internal spaces of buildings.

After created the room schedule the table was generated which contain the (number, name, area) of each room and space inside the buildings and contain the level of each room located in any floor for all buildings. The method of adding "parameter" based on the "parameter" availability in Rivet software (Figure 6 and 7).

\section{Case Study Room Schedule}

The researcher made room schedule for ground and first floor for all buildings. Then calculate actual value of area from Rivet software and comprising it by standard value of area to find the difference between them and to give the recommendations (Figure 8-10).

According to the code used in design the lecture hall and laboratories the area of students is about $86 \%$ from the total area of lecture hall and the area of each student is about $1.9 \mathrm{~m} 2 \mathrm{in}$ lecture hall and $4 \mathrm{~m} 2$ in laboratories ${ }^{12}$. 


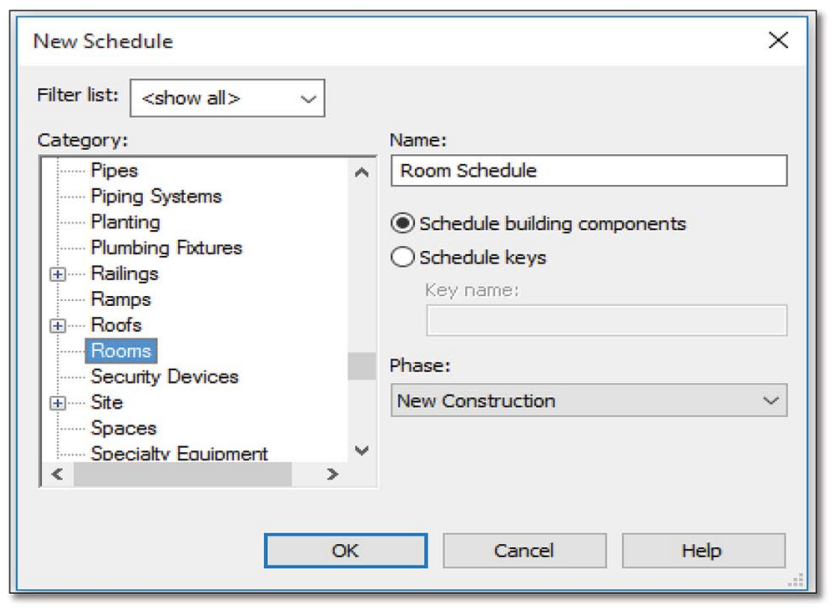

Figure 6. Process of doing room schedule.

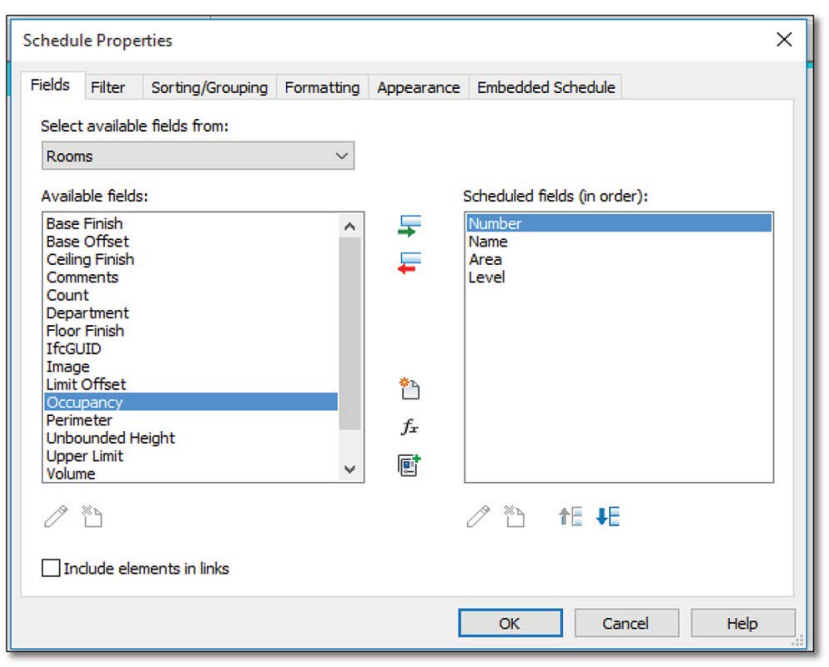

Figure 7. Process of adding parameters.
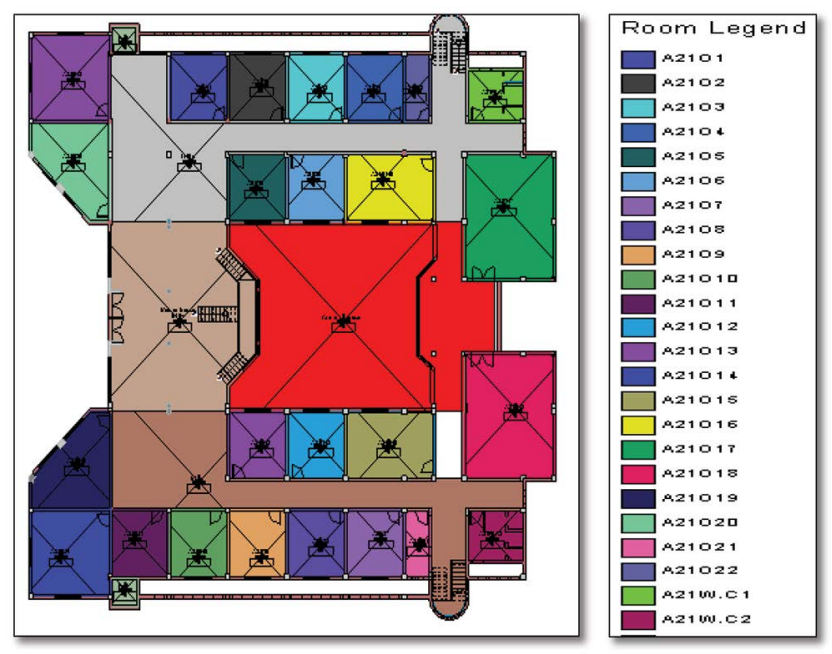

Figure 8. Actual value of internal spaces of ground floor.
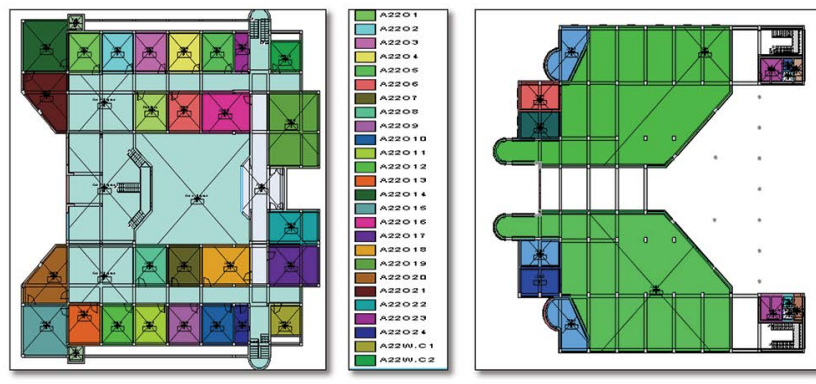

Figure 9. Actual value of internal spaces of first.

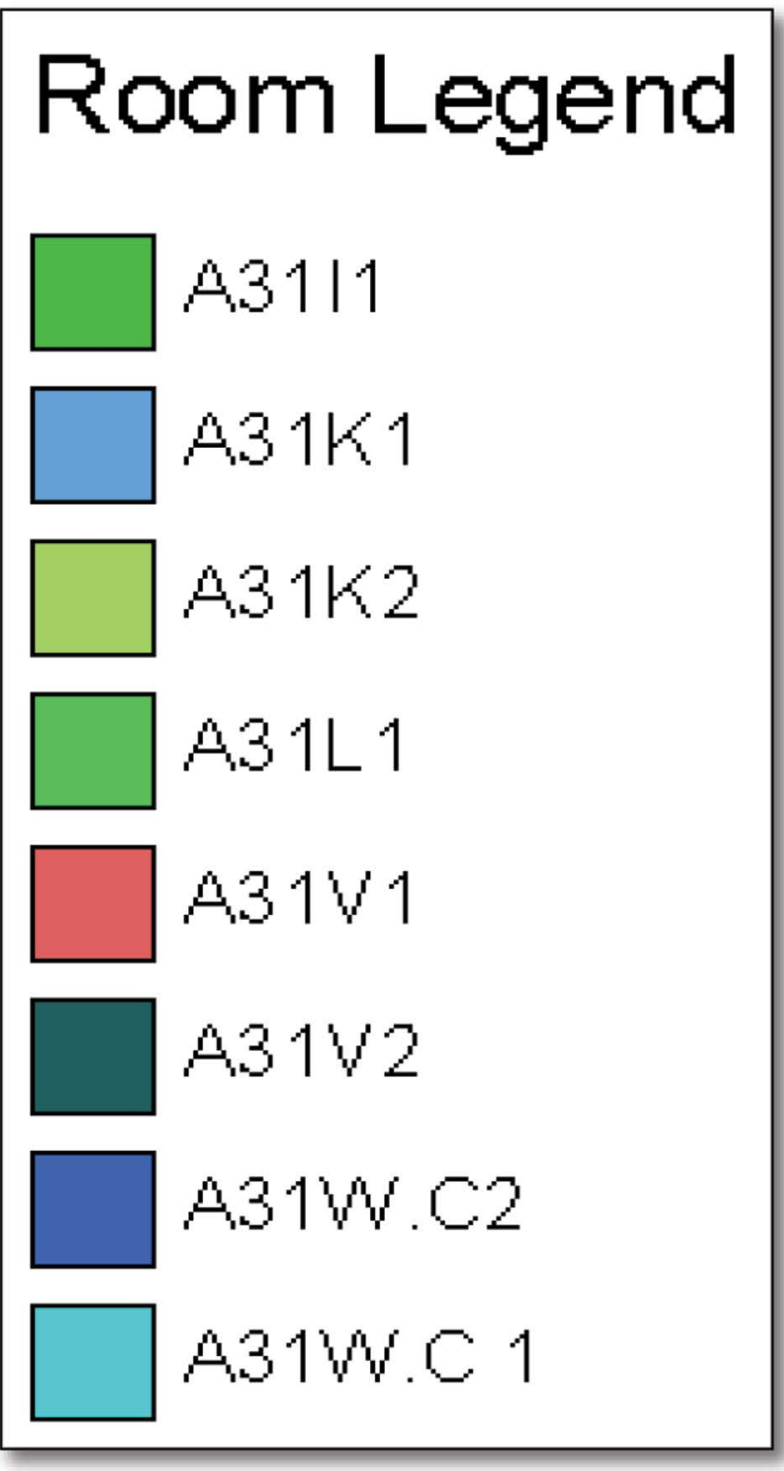

Figure 10. Actual value of internal spaces of ground floor.

According to the code used in the room area for teaching staff is about $22 \mathrm{~m} 2$ for professor and $20 \mathrm{~m} 2$ for assistant and $15 \mathrm{~m} 2$ for lecture ${ }^{12}$. 
According to the code used the room area for staff allocation is about $18 \mathrm{~m} 2$ for two staff and $12 \mathrm{~m} 2$ for one staff and (24-30) $\mathrm{m} 2$ for manager ${ }^{12}$.

The number of student according to standard is calculated by the flowing formula:

$$
\begin{gathered}
\mathrm{Y}=(86 \% \mathrm{AA} / 1.9) \ldots . \text { for student in lecture hall } \\
\mathrm{Y}=(\mathrm{AA} / 4) \ldots \ldots \text { for student in laboratories } \\
\mathrm{E}=\mathrm{X}-\mathrm{Y} \quad(3)
\end{gathered}
$$

Where:

$\mathrm{Y}=$ the number of students according to standard.

$\mathrm{AA}=$ actual value of area.

AS =standard value of area.

$\mathrm{X}=$ the number of students in real.

$\mathrm{E}=$ the difference in the numbers of students.

$\mathrm{Q}=$ Meet the requirements of standard.

\section{Project I (Medicine Collage)}

This project contain (22) room for staff allocation in the ground floor and (24) room in the first floor (Figure 11).

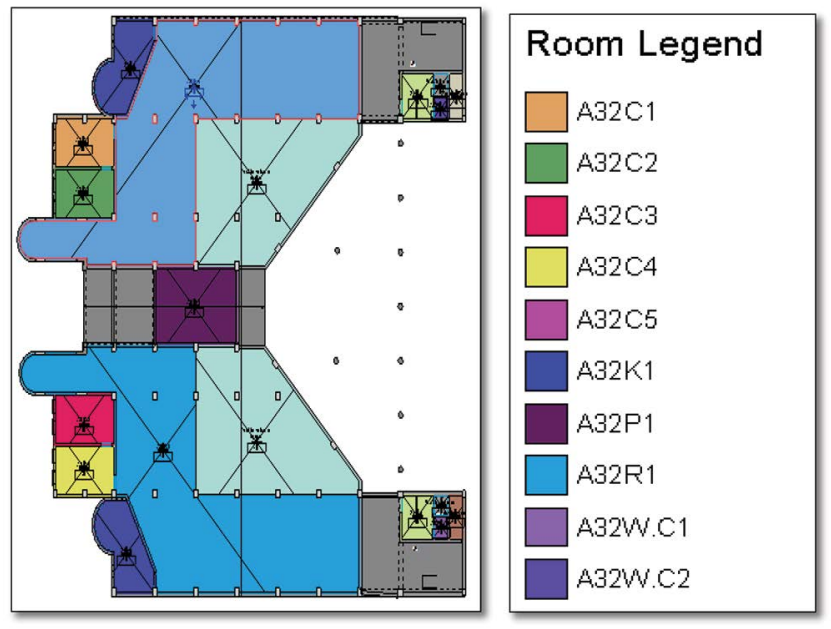

Figure 11. Actual value of internal spaces of ground floor

Table 1 presents the actual value of area for ground floor (project I) is meet the standard requirements except the two room (A21O21, A21O22) are not meet the standard requirement because is don't enough for one staff and need (2) $\mathrm{m} 2$.

Table 2 presents the actual value of area for first floor (project I) is meet the standard requirements except the two room (A22O23, A22O24) are not meet the standard requirement because is don't enough for one staff and need (2) m2.

\begin{tabular}{|c|c|c|c|c|c|}
\hline No. & Name & Level & $\mathrm{AA}(\mathrm{m} 2)$ & AS (m2) & $\mathbf{Q}$ \\
\hline 1. & A2101 & Ground Floor & 22 & 18 & $\mathrm{~V}$ \\
\hline 2. & A 2102 & Ground Floor & 22 & 18 & $\mathrm{v}$ \\
\hline 3. & A2103 & Ground Floor & 22 & 18 & $\mathrm{v}$ \\
\hline 4. & A2104 & Ground Floor & 22 & 18 & $\mathrm{v}$ \\
\hline 5. & A 2105 & Ground Floor & 22 & 18 & $\mathrm{v}$ \\
\hline 6. & A2106 & Ground Floor & 22 & 18 & $\mathrm{v}$ \\
\hline 7. & A 2107 & Ground Floor & 22 & 18 & $\mathrm{v}$ \\
\hline 8. & A2108 & Ground Floor & 22 & 18 & $\mathrm{~V}$ \\
\hline 9. & A2109 & Ground Floor & 22 & 18 & $\mathrm{v}$ \\
\hline 10. & A21010 & Ground Floor & 22 & 18 & $\mathrm{v}$ \\
\hline 11. & A 21011 & Ground Floor & 22 & 18 & $\mathrm{v}$ \\
\hline 12. & A21012 & Ground Floor & 22 & 18 & $\mathrm{v}$ \\
\hline 13. & A 21013 & Ground Floor & 39 & $24-30$ & $\mathrm{v}$ \\
\hline 14. & A21014 & Ground Floor & 39 & 24-30 & $\mathrm{v}$ \\
\hline 15. & A21015 & Ground Floor & 34 & 18 & $\mathrm{v}$ \\
\hline 16. & A21016 & Ground Floor & 34 & 18 & $\mathrm{v}$ \\
\hline 17. & A21017 & Ground Floor & 65 & 30 & $\mathrm{v}$ \\
\hline 18. & A 21018 & Ground Floor & 65 & 30 & $\mathrm{v}$ \\
\hline 19. & A21019 & Ground Floor & 33 & 18 & $\mathrm{v}$ \\
\hline 20. & A21020 & Ground Floor & 33 & 18 & $\mathrm{~V}$ \\
\hline 21. & A21021 & Ground Floor & 10 & 12 & $\mathrm{x}$ \\
\hline 22. & A21022 & Ground Floor & 10 & 12 & $\mathrm{x}$ \\
\hline 23. & A21W.C1 & Ground Floor & 16 & 1 & I \\
\hline 24. & A21W.C2 & Ground Floor & 16 & l & I \\
\hline
\end{tabular}

Table 1. Actual and standard value of area of ground floor

Table 2. Actual and standard value of area of first floor

\begin{tabular}{|c|c|c|c|c|c|}
\hline No. & Name & Level & $\begin{array}{c}\text { AA } \\
(\mathbf{m} 2)\end{array}$ & AS (m2) & Q \\
\hline 1. & A2101 & First Floor & 22 & 18 & V \\
\hline 2. & A2102 & First Floor & 22 & 18 & V \\
\hline 3. & A2103 & First Floor & 22 & 18 & V \\
\hline 4. & A2104 & First Floor & 22 & 18 & V \\
\hline 5. & A2105 & First Floor & 22 & 18 & V \\
\hline 6. & A2106 & First Floor & 22 & 18 & V \\
\hline 7. & A2107 & First Floor & 22 & 18 & V \\
\hline 8. & A2108 & First Floor & 22 & 18 & V \\
\hline 9. & A2109 & First Floor & 22 & 18 & V \\
\hline 10. & A21010 & First Floor & 22 & 18 & V \\
\hline 11. & A21011 & First Floor & 22 & 18 & V \\
\hline 12. & A21012 & First Floor & 22 & 18 & V \\
\hline 13. & A21013 & First Floor & 22 & 18 & V \\
\hline 14. & A21014 & First Floor & 39 & $24-30$ & V \\
\hline 15. & A21015 & First Floor & 39 & $24-30$ & V \\
\hline 16. & A21016 & First Floor & 34 & 18 & V \\
\hline 17. & A21017 & First Floor & 34 & 18 & v \\
\hline 18. & A21018 & First Floor & 34 & 18 & V \\
\hline
\end{tabular}




\begin{tabular}{|c|c|c|c|c|c|}
\hline 19. & A21019 & First Floor & 65 & $/$ & $\mathrm{V}$ \\
\hline 20. & A21020 & First Floor & 33 & 18 & $\mathrm{~V}$ \\
\hline 21. & A21021 & First Floor & 33 & 18 & $\mathrm{~V}$ \\
\hline 22. & A21022 & First Floor & 30 & 18 & $\mathrm{~V}$ \\
\hline 23. & A21023 & First Floor & 10 & 12 & $\mathrm{x}$ \\
\hline 24. & A21024 & First Floor & 10 & 12 & $\mathrm{x}$ \\
\hline 25. & A21W.C1 & First Floor & 16 & $/$ & $/$ \\
\hline 26. & A21W.C2 & First Floor & 16 & $/$ & $/$ \\
\hline
\end{tabular}

\section{Project II (Medicine Collage)}

This project divided for four parties (library, Lecture hall, book store, office room). The ground floor contains two book stores their area about $(27 \mathrm{~m} 2)$ and two free unit their area about $(21 \mathrm{~m} 2)$ the area of library and lecture hall is about $(405 \mathrm{~m} 2)$ Figure 12-15.

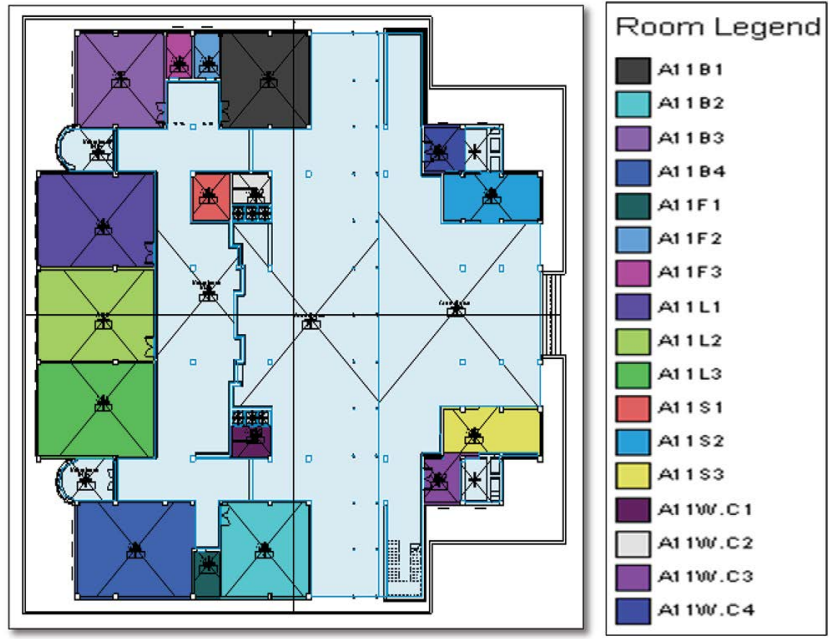

Figure 12. Actual value of internal spaces of ground floor.

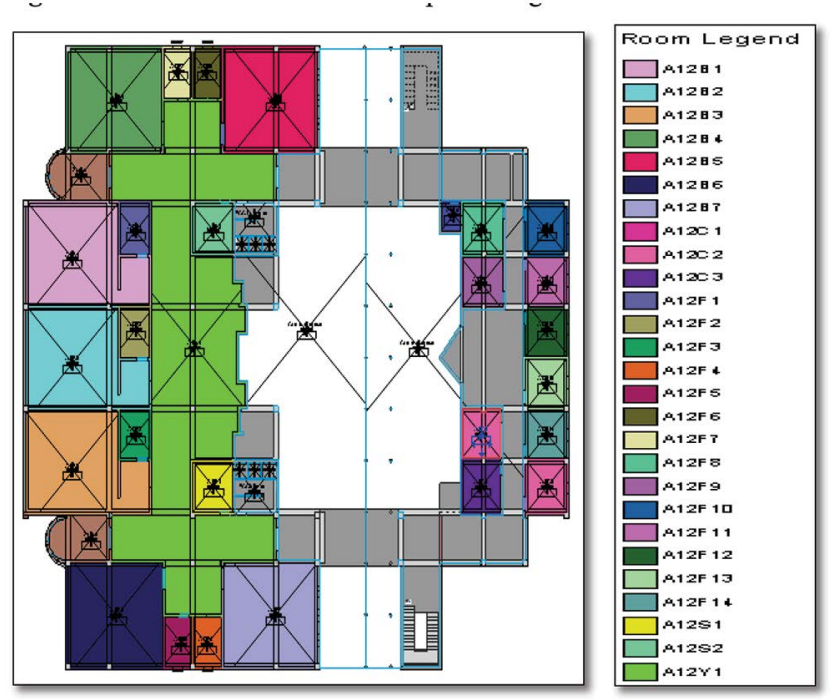

Figure 13. Actual value of internal spaces of first floor.

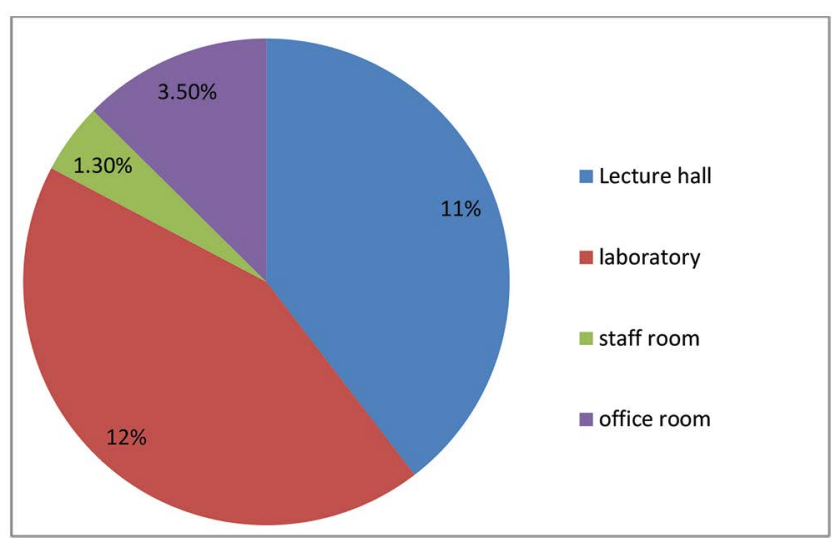

Figre14. Percentage of building details for ground floor.

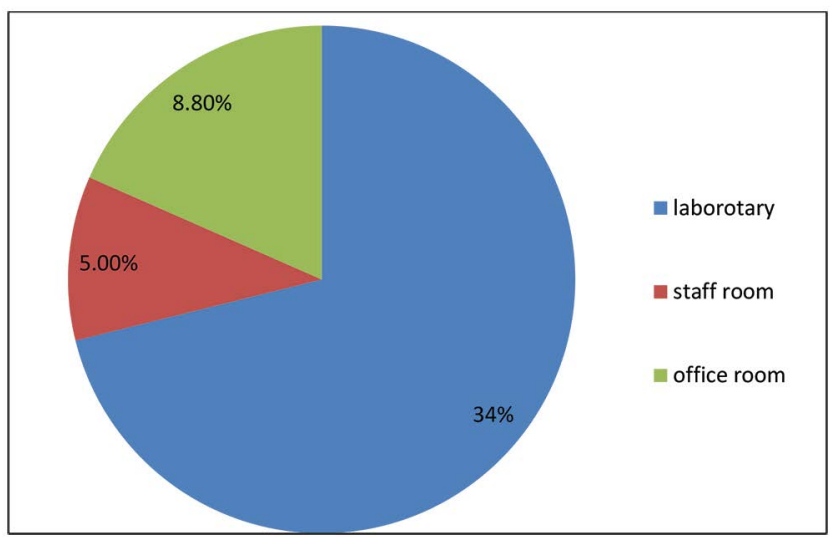

Figure 15. Percentage of building details for first floor.

The first floor contain (5) office room their area about $(21 \mathrm{~m} 2)$, library and book store their area about $(274 \mathrm{~m} 2)$, computer room their area about $(45 \mathrm{~m} 2)$.

\section{Project III (Medicine Collage)}

This project contain (14) room in the ground floor and (22) room in the first floor.

Table 3 presents a big difference between actual value of area that calculated by Revit software according to BIM and standard value of area in the case of staff room need $(10,3,8) \mathrm{m} 2$ to meet staff room requirement. And there are a big difference between the number of students in real and the number of students according to standard in the case of lecture hall the difference is about $(104,53,24)$ and in the case of laboratory the difference is about $(80,51,51,124)$ and don't meet the requirement of standard.

The researcher suggests that the development the buildings reallocating spaces according to international 
Table 3. Actual and standard value of area of ground floor

\begin{tabular}{|c|c|l|c|}
\hline No. & Name & Level & AA (m2) \\
\hline 1. & A31I1 & Ground Floor & 405 \\
\hline 2. & A31L1 & Ground Floor & 405 \\
\hline 3. & A31K1 & Ground Floor & 27 \\
\hline 4. & A31K2 & Ground Floor & 27 \\
\hline 5. & A31V1 & Ground Floor & 21 \\
\hline 6. & A31V2 & Ground Floor & 21 \\
\hline 7. & A31W.C1 & Ground Floor & 14 \\
\hline 8. & A31W.C2 & Ground Floor & 14 \\
\hline
\end{tabular}

standards in order to accommodate the number of existing students and teaching staff or be the number of students suitable for existing spaces.

Table 4-6 present a big difference between actual value of area that calculated by Revit software according to BIM and standard value of area. In the case of teaching staff the spaces don't meet teaching staff room requirement and meet standard requirement in the case of office room.

Table 4. Actual and standard value of area of first floor

\begin{tabular}{|c|c|c|c|}
\hline No. & Name & Level & AA (m2) \\
\hline 1. & A32C1 & First Floor & 21 \\
\hline 2. & A32C2 & First Floor & 21 \\
\hline 3. & A32C3 & First Floor & 21 \\
\hline 4. & A32C4 & First Floor & 21 \\
\hline 5. & A32C5 & First Floor & 21 \\
\hline 6. & A32K1 & First Floor & 274 \\
\hline 7. & A32R1 & First Floor & 274 \\
\hline 8. & A32P1 & First Floor & 45 \\
\hline 9. & A32W.C1 & First Floor & 14 \\
\hline 10. & A32W.C2 & First Floor & 14 \\
\hline
\end{tabular}

Table 5. Actual and standard value of area of ground floor

\begin{tabular}{|l|l|l|l|l|l|l|l|l|}
\hline c & Name & Level & $\begin{array}{l}\text { AA } \\
(\mathbf{m} 2)\end{array}$ & $\begin{array}{l}\text { AS } \\
(\mathbf{m} 2)\end{array}$ & $\mathbf{X}$ & Y & E & Q \\
\hline 1. & A11L1 & $\begin{array}{l}\text { Ground } \\
\text { Floor }\end{array}$ & 103 & $/$ & 150 & 46 & 104 & $\mathrm{x}$ \\
\hline 2. & A11L2 & $\begin{array}{l}\text { Ground } \\
\text { Floor }\end{array}$ & 103 & $/$ & 99 & 46 & 53 & $\mathrm{x}$ \\
\hline 3. & A11L3 & $\begin{array}{l}\text { Ground } \\
\text { Floor }\end{array}$ & 103 & $/$ & 70 & 46 & 24 & $\mathrm{x}$ \\
\hline
\end{tabular}

\begin{tabular}{|l|l|l|l|l|l|l|l|l|}
\hline 4. & A11B1 & $\begin{array}{l}\text { Ground } \\
\text { Floor }\end{array}$ & 79 & $/$ & 99 & 19 & 80 & $\mathrm{x}$ \\
\hline 5. & A11B2 & $\begin{array}{l}\text { Ground } \\
\text { Floor }\end{array}$ & 79 & $/$ & 70 & 19 & 51 & $\mathrm{x}$ \\
\hline 6. & A11B3 & $\begin{array}{l}\text { Ground } \\
\text { Floor }\end{array}$ & 79 & $/$ & 70 & 19 & 51 & $\mathrm{x}$ \\
\hline 7. & A11B4 & $\begin{array}{l}\text { Ground } \\
\text { Floor }\end{array}$ & 106 & $/$ & 150 & 26 & 124 & $\mathrm{x}$ \\
\hline 8. & A11F1 & $\begin{array}{l}\text { Ground } \\
\text { Floor }\end{array}$ & 12 & 22 & $/$ & $/$ & $/$ & $\mathrm{x}$ \\
\hline 9. & A11F2 & $\begin{array}{l}\text { Ground } \\
\text { Floor }\end{array}$ & 12 & 15 & $/$ & $/$ & $/$ & $\mathrm{x}$ \\
\hline 10. & A11F3 & $\begin{array}{l}\text { Ground } \\
\text { Floor }\end{array}$ & 12 & 20 & $/$ & $/$ & $/$ & $\mathrm{x}$ \\
\hline 11. & A11S1 & $\begin{array}{l}\text { Ground } \\
\text { Floor }\end{array}$ & 16 & $/$ & $/$ & $/$ & $/$ & $\mathrm{x}$ \\
\hline 12. & A11S2 & $\begin{array}{l}\text { Ground } \\
\text { Floor }\end{array}$ & 16 & $/$ & $/$ & $/$ & $/$ & $\mathrm{x}$ \\
\hline 13. & A11S3 & $\begin{array}{l}\text { Ground } \\
\text { Floor }\end{array}$ & 16 & $/$ & $/$ & $/$ & $/$ & $\mathrm{x}$ \\
\hline 14. & $\begin{array}{l}\text { A11W. } \\
\text { C1 }\end{array}$ & $\begin{array}{l}\text { Ground } \\
\text { Floor }\end{array}$ & 16 & $/$ & $/$ & $/$ & $/$ & $\mathrm{x}$ \\
\hline 15. & $\begin{array}{l}\text { A11W. } \\
\text { C2 }\end{array}$ & $\begin{array}{l}\text { Ground } \\
\text { Floor }\end{array}$ & 16 & $/$ & $/$ & $/$ & $/$ & $\mathrm{x}$ \\
\hline 16. & $\begin{array}{l}\text { A11W. } \\
\text { C3 }\end{array}$ & $\begin{array}{l}\text { Ground } \\
\text { Floor }\end{array}$ & 16 & $/$ & $/$ & $/$ & $/$ & $\mathrm{x}$ \\
\hline 17. & $\begin{array}{l}\text { A11W. } \\
\text { C4 }\end{array}$ & $\begin{array}{l}\text { Ground } \\
\text { Floor }\end{array}$ & 16 & $/$ & $/$ & $/$ & $/$ & $/$ \\
\hline
\end{tabular}

Table 6. Actual and standard value of area of first floor

\begin{tabular}{|c|c|c|c|c|c|c|c|c|}
\hline No. & Name & Level & $\begin{array}{c}\text { AA } \\
(\mathbf{m} 2)\end{array}$ & $\begin{array}{c}\text { AS } \\
(\mathbf{m} 2)\end{array}$ & $\mathbf{X}$ & Y & E & Q \\
\hline 1. & A12B1 & $\begin{array}{c}\text { First } \\
\text { Floor }\end{array}$ & 88 & $/$ & 150 & 22 & 128 & $\mathrm{x}$ \\
\hline 2. & A12B2 & $\begin{array}{c}\text { First } \\
\text { Floor }\end{array}$ & 88 & $/$ & 99 & 22 & 77 & $\mathrm{x}$ \\
\hline 3. & A12B3 & $\begin{array}{c}\text { First } \\
\text { Floor }\end{array}$ & 88 & $/$ & 70 & 22 & 48 & $\mathrm{x}$ \\
\hline 4. & A12B4 & $\begin{array}{c}\text { First } \\
\text { Floor }\end{array}$ & 79 & $/$ & 70 & 19 & 51 & $\mathrm{x}$ \\
\hline 5. & A12B5 & $\begin{array}{c}\text { First } \\
\text { Floor }\end{array}$ & 79 & $/$ & 150 & 19 & 131 & $\mathrm{x}$ \\
\hline 6. & A12B6 & $\begin{array}{c}\text { First } \\
\text { Floor }\end{array}$ & 79 & $/$ & 99 & 19 & 80 & $\mathrm{x}$ \\
\hline 7. & A12B7 & $\begin{array}{c}\text { First } \\
\text { Floor }\end{array}$ & 79 & $/$ & 70 & 19 & 51 & $\mathrm{x}$ \\
\hline
\end{tabular}




\begin{tabular}{|c|c|c|c|c|c|c|c|c|}
\hline 8. & $\mathrm{~A} 12 \mathrm{~F} 1$ & $\begin{array}{l}\text { First } \\
\text { Floor }\end{array}$ & 12 & 15 & I & I & 3 & $\mathrm{x}$ \\
\hline 9. & $\mathrm{~A} 12 \mathrm{~F} 2$ & $\begin{array}{c}\text { First } \\
\text { Floor }\end{array}$ & 12 & 15 & I & I & 3 & $\mathrm{x}$ \\
\hline 10. & $\mathrm{~A} 12 \mathrm{~F} 3$ & $\begin{array}{l}\text { First } \\
\text { Floor }\end{array}$ & 12 & 15 & l & I & 3 & $\mathrm{x}$ \\
\hline 11. & $\mathrm{~A} 12 \mathrm{~F} 4$ & $\begin{array}{l}\text { First } \\
\text { Floor }\end{array}$ & 12 & 15 & I & I & 3 & $\mathrm{x}$ \\
\hline 12. & A12F5 & $\begin{array}{l}\text { First } \\
\text { Floor }\end{array}$ & 16 & 22 & I & I & 6 & $\mathrm{x}$ \\
\hline 13. & A12F6 & $\begin{array}{l}\text { First } \\
\text { Floor }\end{array}$ & 16 & 22 & I & I & 6 & $\mathrm{x}$ \\
\hline 14. & A12F7 & $\begin{array}{c}\text { First } \\
\text { Floor }\end{array}$ & 16 & 22 & I & I & 6 & $\mathrm{x}$ \\
\hline 15. & A12F8 & $\begin{array}{l}\text { First } \\
\text { Floor }\end{array}$ & 16 & 20 & I & I & 4 & $\mathrm{x}$ \\
\hline 16. & A12F9 & $\begin{array}{l}\text { First } \\
\text { Floor }\end{array}$ & 16 & 22 & l & I & 6 & $\mathrm{x}$ \\
\hline 17. & A12F10 & $\begin{array}{l}\text { First } \\
\text { Floor }\end{array}$ & 16 & 22 & I & I & 6 & $\mathrm{x}$ \\
\hline 18. & A12F11 & $\begin{array}{c}\text { First } \\
\text { Floor }\end{array}$ & 16 & 22 & I & I & 6 & $\mathrm{x}$ \\
\hline 19. & $\mathrm{~A} 12 \mathrm{~F} 12$ & $\begin{array}{l}\text { First } \\
\text { Floor }\end{array}$ & 16 & 22 & I & I & 6 & $\mathrm{x}$ \\
\hline 20. & A12F13 & $\begin{array}{l}\text { First } \\
\text { Floor }\end{array}$ & 16 & 22 & I & I & 6 & $\mathrm{x}$ \\
\hline 21. & A12F14 & $\begin{array}{l}\text { First } \\
\text { Floor }\end{array}$ & 16 & 21 & I & I & 6 & $\mathrm{x}$ \\
\hline 22. & A12S1 & $\begin{array}{l}\text { First } \\
\text { Floor }\end{array}$ & 16 & I & l & I & I & $\mathrm{x}$ \\
\hline 23. & $\mathrm{~A} 12 \mathrm{C} 1$ & $\begin{array}{l}\text { First } \\
\text { Floor }\end{array}$ & 16 & 12 & I & I & I & $\mathrm{x}$ \\
\hline 24. & $\mathrm{~A} 12 \mathrm{C} 2$ & $\begin{array}{l}\text { First } \\
\text { Floor }\end{array}$ & 16 & 12 & l & I & / & $\mathrm{x}$ \\
\hline 25. & A12C3 & $\begin{array}{l}\text { First } \\
\text { Floor }\end{array}$ & 16 & 12 & I & I & / & $\mathrm{x}$ \\
\hline 26. & A12W.C1 & $\begin{array}{l}\text { First } \\
\text { Floor }\end{array}$ & 16 & I & I & I & 1 & $\mathrm{x}$ \\
\hline 27. & A12W.C2 & $\begin{array}{l}\text { First } \\
\text { Floor }\end{array}$ & 16 & / & l & I & I & $\mathrm{x}$ \\
\hline
\end{tabular}

standards in order to accommodate the number of existing students and teaching staff or re-study acceptance plans to be the number of students suitable for existing spaces.

\section{Conclusions}

Depending on the literature review and the case study analysis the following conclusions are made:

1. The BIM technology is working to increase the cooperation between project team and this lead to reducing the conflicts and increasing the efficiency of the project by reducing time and cost.

2. The use of BIM technology in site planning and space management is relatively low.

3. It is easy to obtain space data through the use of the Revit software according to BIM technology and make comparison with international standard.

4. Revit software according to BIM technology is an effective tool that provides the users with a good visualization and documentation when compared to the traditional method.

\section{Reference}

1. Kim H, Anderson K, Lee S, Hildreth J. Generating construction schedules through automatic data extraction using open BIM (Building Information Modeling) technology, Automation in Construction. 2013; 35:285-95. https:// doi.org/10.1016/j.autcon.2013.05.020.

2. Barlish K, Sullivan K. How to measure the benefits of BIM-A case study approach, Automation in Construction. 2012; 24:149-59. https://doi.org/10.1016/j.autcon.2012.02.008.

3. Building Information Modeling (BIM): Site-Building Interoperability Methods. Date accessed: 09/2011. https:// web.wpi.edu/Pubs/ETD/Available/etd-090711-090955/ unrestricted/mwang.pdf.

4. Azhar S, Nadeem A, Mok JY, Leung BH. Building Information Modeling (BIM): A new paradigm for visual interactive modeling and simulation for construction projects. In: Proceedings First International Conference on Construction in Developing Countries; 2008, 1. p. $435-46$. students in real and the number of students according to standard I $\mathrm{n}$ the case of laboratory the difference is about $(128,77,48,51,131,80,51)$ and don't meet the requirement of standard.

The researcher suggests that the development the buildings reallocating spaces according to international

5. Crawford L, Nahmias AH. Competencies for managing change, International Journal of Project Management. 2010; 28(4):405-12. https://doi.org/10.1016/j.ijproman.2010.01.015. 
6. Sebastian R. Changing roles of the clients, architects and contractors through BIM, Engineering, Construction and Architectural Management. 2011; 18(2):176-87. https:// doi.org/10.1108/09699981111111148.

7. Redmond A, Hore A, Alshawi M, West R. Exploring how information exchanges can be enhanced through Cloud BIM, Automation in Construction. 2012; 24:175-83. https://doi.org/10.1016/j.autcon.2012.02.003.

8. Abbasnejad B, Moud HI. BIM and basic challenges associated with its definitions, interpretations and expectations, International Journal of Engineering Research and Applications (IJERA). 2013; 3(2):287-94.
9. Khosrowshahi F, Arayici Y. Roadmap for implementation of BIM in the UK construction industry, Engineering, Construction and Architectural Management. 2012; 19(6):610-35.https://doi.org/10.1108/09699981211277531.

10. Bryde D, Broquetas M, Volm JM. The project benefits of building information modelling (BIM), International Journal of Project Management. 2013; 31(7):971-80. https://doi.org/10.1016/j.ijproman.2012.12.001

11. Holzer D. BIM's seven deadly sins, International Journal of Architectural Computing. 2011; 9(4):463-80. https://doi. org/10.1260/1478-0771.9.4.463. Date accessed: 08/07/2017.

12. Architects' Data. https://en.wikipedia.org/wiki/ Architects\%27_Data. 